\title{
ANALISIS PERSEPSI PENGUNJUNG DALAM PENGELOLAAN LEBAH MADU UNTUK MENDUKUNG KEGIATAN EKOWISATA DI DESA KECAPI, KALIANDA, LAMPUNG SELATAN
}

\author{
Analysis of Tourists' Perceptions of Honey Bee Management to Support Ecotourism \\ Activities in Kecapi Village, Kalianda, South Lampung
Aulia Nur Intan Denada*, Gunardi Djoko Winarno, Dian Iswandaru, Yulia Rahma Fitriana \\ Jurusan Kehutanan, Fakultas Pertanian, Universitas Lampung \\ Jln. Prof. Dr. Soemantri Brojonegoro No. 1 Gedung Meneng, Bandar Lampung \\ *Email: aulianurintandj@gmail.com
}

Direvisi: 07/07/2020, Diterbitkan: 01/08/2020

\begin{abstract}
Kebun Lebah Simpur (KLS) is one of the locations of Trigona spp bee cultivation which is quite large because it has become a reference for honey bee managers both from domestic and abroad. KLS is located in Lampung Province and has the potential to be developed into an ecotourism destination but the manager has been focusing on the cultivation and marketing of bee products. This study aims to analyze visitor perceptions regarding the management of KLS honey bees to support ecotourism activities. Data collection in this study uses the interview method with a questionnaire tool to visitors based on purposive sampling and in-depth interviews with managers to complete information about the management of KLS. The questionnaire contained questions about visitors' perceptions about KLS management based on the $4 A$ ecotourism factor (attraction, accessibility, amenities and ancillary) with reference to Likert scale assessment. The results were then analyzed descriptively qualitatively. The results of the analysis show that the aspect of attraction is classified as good, while the visitor's perception of the accessibility, amenities and ancillary factors is still relatively neutral so development still needs to be done.
\end{abstract}

Keywords; Ecotourism, cultivation of bees, tourists, perception.

\begin{abstract}
ABSTRAK
Kebun Lebah Simpur (KLS) merupakan salah satu lokasi budidaya lebah Trigona spp yang cukup besar karena telah menjadi rujukan bagi pengelola lebah madu baik dari dalam maupun luar negeri. KLS terdapat di Provinsi Lampung dan memiliki potensi untuk dikembangkan menjadi suatu destinasi ekowisata namun selama ini pengelola masih berfokus pada kegiatan budidaya dan pemasaran hasil lebah. Penelitian ini bertujuan untuk menganalisis persepsi pengunjung mengenai pengelolaan lebah madu KLS untuk mendukung kegiatan ekowisata. Pengumpulan data pada penelitian ini menggunakan metode wawancara dengan alat bantu kuesioner kepada pengunjung yang berdasarkan purposive sampling dan wawancara mendalam kepada pengelola untuk melengkapi informasi seputar pengelolaan KLS. Kuesioner berisi pertanyaan seputar persepsi pengunjung tentang pengelolaan KLS yang didasarkan pada faktor $4 \mathrm{~A}$ ekowisata
\end{abstract}


(attraction, accesability, amenities dan ancillary) dengan acuan penilaian skala likert. Hasil kemudian dianalisis secara deskriptif kualitatif. Hasil analisis menunjukkan bahwa aspek attraction tergolong baik, sedangkan persepsi pengunjung mengenai faktor accesability, amenities dan ancillary masih tergolong netral sehingga masih perlu dilakukan pengembangan.

Kata kunci; ekowisata, budidaya lebah, pengunjung, persepsi.

\section{PENDAHULUAN}

Pariwisata merupakan sektor penyumbang devisa negara terbesar (Widyarini dan Sunarta, 2018) dan sedang dikembangkan di berbagai wilayah termasuk Provinsi Lampung (Sari et al, 2015). Ekowisata merupakan salah satu konsep pengembangan pariwisata (Bramsah dan Darmawan, 2017) yang menjadi alternatif pengembangan wisata berkelanjutan (Sadiarta, 2006), untuk dapat melakukan pemanfaatan secara bijaksana dan mengusahakan pemanfaatan sumber daya alam hayati dan ekosistemnya tetap lestari (Nugroho, 2011).

Budiidaya lebah madu merupakan salah satu sektor yang sedang berkembang di Provinsi Lampung saat ini. Selama ini tujuan utama dilakukannya kegiatan budidaya lebah madu adalah memenuhi kebutuhan individu (Adalina, 2011) terutama bila kegiatan ini dilakukan dengan tepat guna maka akan memberikan keuntungan (Sya'ban et al, 2014). Selain dapat menghasilkan produk madu budidaya lebah madu juga berpotensi untuk dikembangkan menjadi kegiatan ekowisata (Widowati, 2014).

Kebun Lebah Simpur (KLS) merupakan salah satu lokasi budidaya lebah madu yang terdapat di Provinsi Lampung tepatnya di Desa Kecapi, Kalianda, Lampung Selatan. KLS merupakan lokasi budidaya lebah Trigona spp yang cukup besar karena telah menjadi rujukan para pengelola lebah dari berbagai daerah baik dari dalam maupun luar negeri. KLS memiliki potensi untuk dikembangkan menjadi destinasi ekowisata, namun selama ini KLS masih berfokus pada pemasaran hasil madu dan propolis saja. Persepsi pengunjung sangat penting dalam pengembangan ekowisata untuk diketahui (Prasetyo et al, 2019) sehingga dapat dijadikan sebagai salah satu acuan dalam pengembangannya. Oleh karena itu diperlukan penelitian ini yang bertujuan untuk menganalisis persepsi pengunjung mengenai pengelolaan lebah madu untuk mendukung kegiatan ekowisata di Desa Kecapi, Kalianda, Lampung Selatan.

\section{METODE}

Penelitian ini dilakukan di Desa kecapi, Kalianda, Lampung Selatan (Gambar 1), terletap pada koordinat $5,72^{\circ}-5,76^{\circ}$ LS dan $105,60^{\circ}-105,61^{\circ}$ BT dari bulan September hingga Desember 2019. Objek penelitian ini adalah pengunjung KLS. Alat yang digunakan dalam penelitian ini adalah laptop, kamera, alat tulis dan kuesioner. 


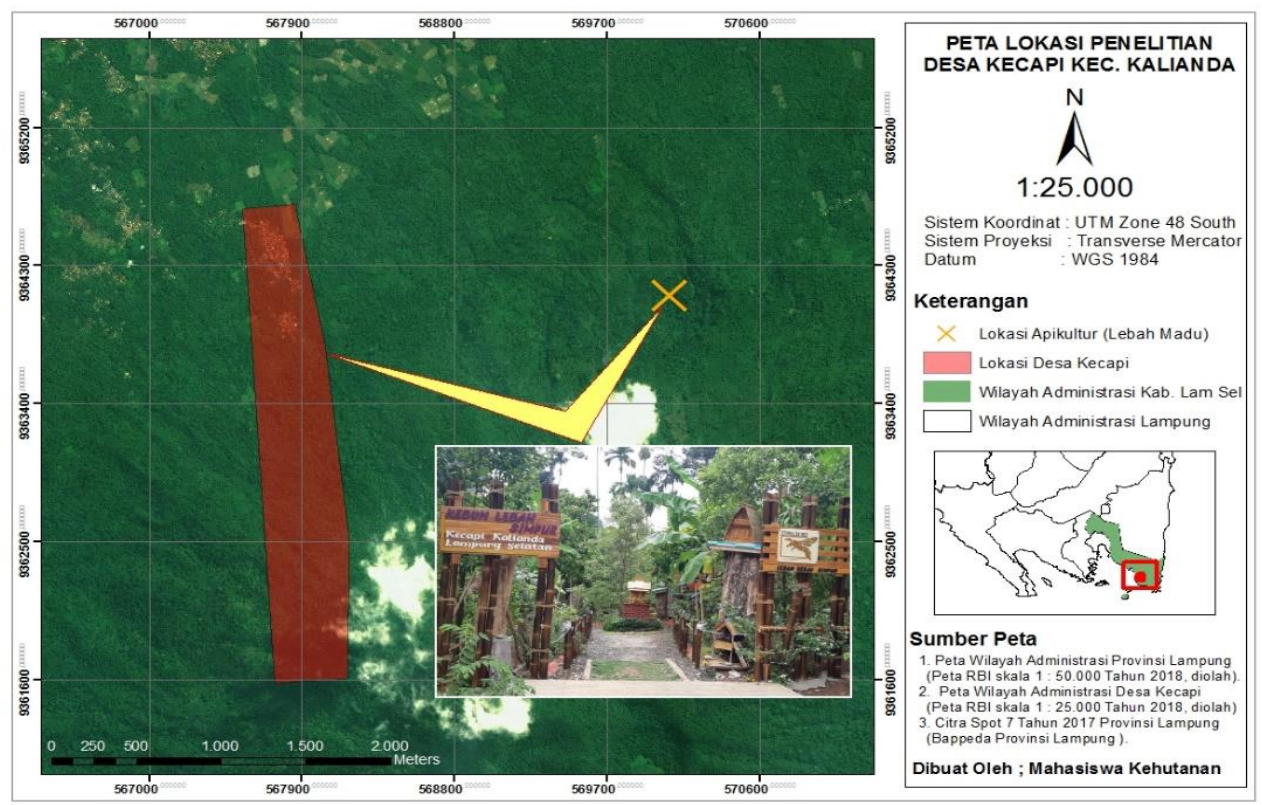

Gambar 1. Peta lokasi penelitian. Figure 1. Map of research location.

Pengumpulan data dilakukan menggunakan metode wawancara dengan alat bantu berupa kuesioner. Wawancara dilakukan kepada pengunjung yang berasal dari luar desa Desa Kecapi, dengan kriteria umur 15 sampai 55 tahun (Purnawingsih dan Rosa, 2015) yang dipilih dengan teknik purposive sampling, yaitu dengan melakukan penentuan informan yang didasarkan pada pertimbangan tertentu serta memiliki kemauan dan kemampuan untuk memberikan data terkait keperluan penelitian (Juwita, 2015). Wawancara mendalam dan pengamatan (Hajriati dan Mardiana, 2014) dilakukan guna memenuhi keterangan (Dewi, 2013) seputar pengelolaan kepada pihak pengelola. Kuesioner yang diberikan kepada pengunjung berupa pertanyaan mengenai pengelolaan lebah madu di KLS yang didasarkan pada aspek 4A ekowisata (Attraction, Accesability, Amenities dan Ancillary service) dan menggunakan acuan penilaian skala likert. Data yang telah didapatkan kemudian dianalisis menggunakan analisis deskriptif kualitatif (Sugiyono, 2013).

Tabel 1. Penilaian Skala Likert dalam Penelitian

Table 1. Likert Scale Rating in Research

\begin{tabular}{lcc}
\hline & Pernyataan & Nilai \\
\hline Sangat Setuju & 5 \\
Setuju & 4 \\
Netral & 3 \\
Tidak Setuju & 2 \\
Sangat Tidak Setuju & 1 \\
\hline
\end{tabular}

Sumber: Sugiyono (2014)

1. Rumus perhitungan skala likert menggunakan 5 alternatif jawaban

$\mathrm{NL}=\sum\left(n_{1} \times 1\right)+\left(n_{2} \times 2\right)+\left(n_{3} \times 3\right)+\left(n_{4} \times 4\right)+\left(n_{5} \times 5\right)$

Keterangan:

$\mathrm{NL}=$ nilai scoring skala likert

$\mathrm{N}$ = jumlah jawaban score (alternatif skor skala likert 1 sampai 5 ) 
2. Rumus perhitungan rata-rata tiap aspek pertanyaan

Keterangan:

$$
Q=\frac{N L}{x}
$$

$Q$ = rata-rata tiap aspek pertanyaan

$\mathrm{NL}=$ nilai scoring skala likert

$\mathrm{X}=$ jumlah sampel responden

3. Rumus nilai akhir tiap aspek

$$
N A=\frac{Q 1+Q 2+Q 3+Q 4+\cdots Q n}{n}
$$

Keterangan:

$\mathrm{NA}=$ nilai akhir

$\mathrm{Q}=$ Rata-rata tiap aspek pertanyaan (meggunakan 5 skala )

Jumlah sampel ditentukan dengan menggunakan rumus slovin, dan didapatkan jumlah responden sebanyak 44 orang.

4. Rumus penentuan jumlah responden

$$
n=\frac{N}{1+N(e)^{2}}
$$

Pengunjung: $n=\frac{4800}{1+4800(0,15)^{2}}=44$ responden

Keterangan:

$\mathrm{n}=$ Ukuran sampel/jumlah responden

$\mathrm{N}=$ Ukuran populasi

$\mathrm{E}=$ Presentase kelonggaran ketelitian kesalahan pengambilan sampel yang masih bisa ditolerir; $e=15 \%$

Sumber : Sugiyono (2014).

Penggunaan acuan ini dianggap mampu mewakili jumlah responden (Astriyantika et al, 2015) dan mengukur sifat dan pengetahuan (Budiaji, 2013) pengunjung mengenai pengelolaan budidaya lebah madu KLS untuk dikembangkan menjadi destinasi ekowisata.

\section{HASIL DAN PEMBAHASAN,}

\section{A. Analisis Persepsi Daya Tarik (Attraction) Pegunjung}

Analisis persepsi daya tarik (attraction) oleh pengunjung didasarkan pada 5 indikator pertanyaan meliputi, pengelolaan, kondisi alam, ketersediaan pakan, ketersediaan sarang dan partisipasi pengunjung (Gambar 2). 
Jurnal Belantara Vol. 3, No. 2, Agustus 2020 (153-162)

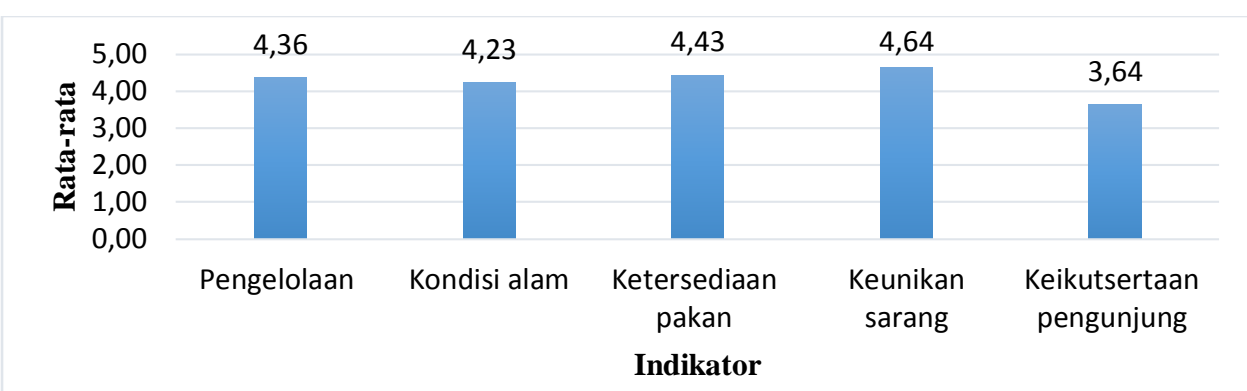

Gambar 2. Analisis persepsi daya tarik KLS

Figure 2. Perception analysis of KLS attraction

Hasil analisis daya tarik (attraction) oleh pengunjung menunjukkan bahwa rata-rata penilaian terbesar terdapat pada indikator keunikan sarang. Pengunjung KLS menyatakan bahwa rumah lanceng (sarang) lebah dinilai unik, karena memiliki bentuk yang beragam seperti rumah adat, alat transportasi, hewan dan bentuk lainnya. Indikator mengenai pengelolaan budidaya, kondisi alam dan ketersediaan pakan tergolong baik. Pengunjung menilai bahwa lokasi budidaya tersusun dengan baik. hal ini didukung dengan keberadaan berbagai macam bunga sebagai pakan utama lebah.

Lokasi budidaya lebah madu KLS dinilai sejuk, hal ini disebabkan banyaknya tumbuhan maupun pepohonan yang mengelilingi lokasi tersebut. Beberapa jenis pohon yang dapat ditemukan di KLS antara lain matoa (Pometia pinata), durian (Durio zibethinus), petai (Parkia speciosa), nangka (Artocarpus heterophyllus), dan tanaman coklat (Pometia pinnata). Sedangkan indikator mengenai partisipasi pengunjung memiliki rata-rata terkecil. Kurangnya partisipasi pengunjung di KLS disebabkan pengunjung yang belum memiliki pemahaman mengenai lebah Trigona spp. Masih banyak pengunjung yang takut tersengat selama proses pemanenan, sehingga kegiatan ini hanya akan dilaksanakan berdasarkan permintaan pengunjung. Kurangnya kegiatan atau partisipasi pengunjung sangatlah disayangkan karena pengalaman dan kegiatan pengunjung menjadi terbatas (Khotimah et al, 2017). Melalui kegiatan wawancara yang dilakukan, diketahui bahwa sebagian pengunjung hanya memilih untuk menunggu produk madu hasil produksi dibandingkan harus ikut serta dalam kegiatan pemanenan. Meskipun demikian, hasil analisis persepsi pengunjung menunjukkan bahwa daya tarik (attraction) KLS tergolong baik.

\section{B. Analisis Aksebilitas (Accesability) oleh Pengunjung}

Analisis aksebilitas (accesability) oleh pengunjung didasarkan pada 4 indikator pertanyaan meliputi ketersediaan jalan, kualitas dan kondisi jalan, transportasi umum dan petunjuk jalan (Gambar 3).

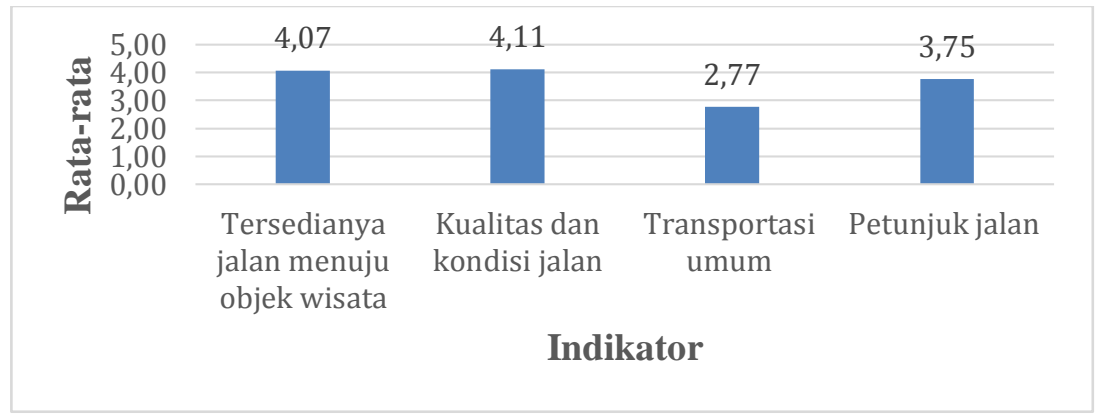

Gambar 3. Analisis persepsi aksebilitas KLS

Figure 3. Perception analys of KLS accesability 
Hasil analisis persepsi pengunjung mengenai aksebilitas (accesability) menunjukkan bahwa indikator pertanyaan mengenai ketersediaan jalan tergolong baik. Kondisi ini didukung dengan kualitas dan kondisi jalan menuju KLS yang memiliki rata-rata tertinggi. Meskipun jalan yang tersedia tidak terlalu besar, namun pengunjung menilai bahwa jalan menuju lokasi LKS dalam kondisi baik, shingga mudah untuk dilalui.

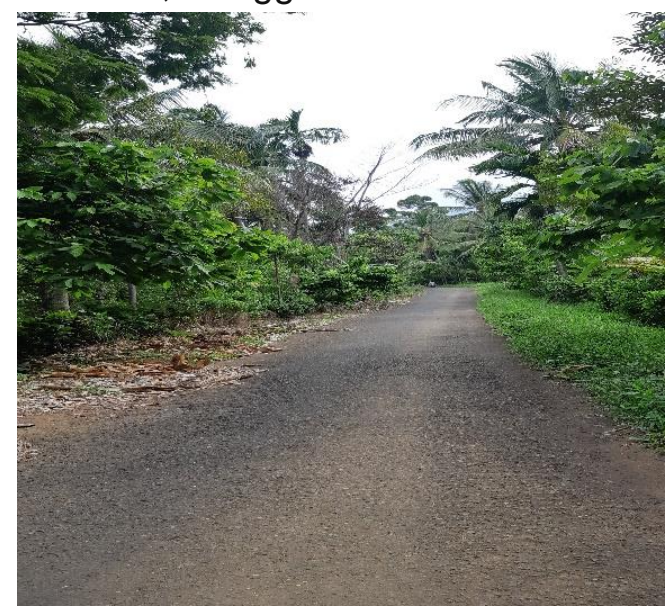

Gambar 4. Kondisi jalan menuju KLS

Figure 4. Road condition to KLS

Persepsi pengunjung mengenai ketersediaan petunjuk jalan tergolong netral. Namun, pengunjung tidak terlalu mempermasalahkan hal tersebut karena akses menuju KLS yang tergolong mudah dan banyak masyarakat yang telah mengetahui keberadaan KLS sehingga memudahkan pengunjung untuk mendapatkan informasi. Indikator transportasi memiliki nilai terkecil, hal ini disebabkan belum ada transportasi umum yang khusus mengantarkan pengunjung menuju lokasi KLS. Selain itu, melalui kegiatan wawancara yang dilakukan diketahui bahwa pengunjung datang ke KLS lebih memilih untuk menggunakan kendaraan pribadi.

Analisis yang dilakukan berdasarkan 4 indikator pertanyaan menunjukkan bahwa persepsi pengunjung mengenai faktor aksebilitas yang terdapat di KLS bersifat netral, sehingga perlu dilakukannya perbaikan terhadap faktor ini. Pengunjung berharap agar dilakukannya penambahan petunjuk jalan dan transportasi umum. Terpenuhinya faktor aksebilitas yang memadai akan memberikan kemudahan bagi pengunjung untuk mendatangi lokasi tersebut (Khotimah et al, 2017).

\section{Analisis Fasilitas (Amenities) Oleh Pengunjung}

Analisis fasilitas (amenities) oleh pengunjung didasarkan pada 4 indikator pertanyaan meliputi toilet, gazebo, tempat ibadah dan jalan setapak (Gambar 4). 
Jurnal Belantara Vol. 3, No. 2, Agustus 2020 (153-162)

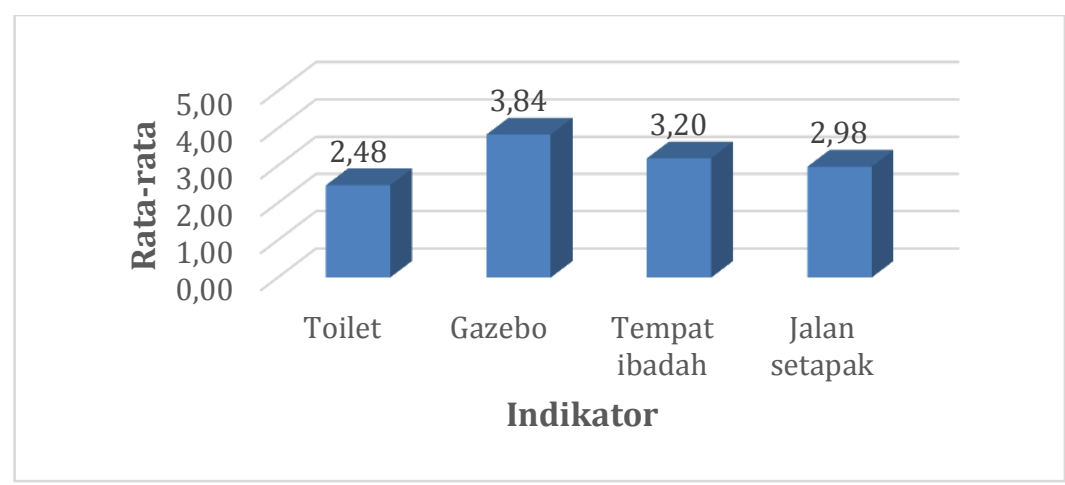

Gambar 5. Analisis persepsi fasilitas KLS

Figure 5. Perception analys of KLS amenities

Hasil analisis persepsi pengunjung mengenai fasilitas (amenities) KLS menunjukkan bahwa ketersediaan gazebo sebaga tempat untuk beristirahat memiliki nilai rata-rata tertinggi. Namun hasil ini masih tergolong dalam skala netral atau cukup. Melalui kegiatan observasi yang dilakukan bahwa hanya terdapat 1 gazebo berukuran besar yang diperuntukkan sebagai tempat istirahat sekaligus beribadah bagi pengunjung yang datang.

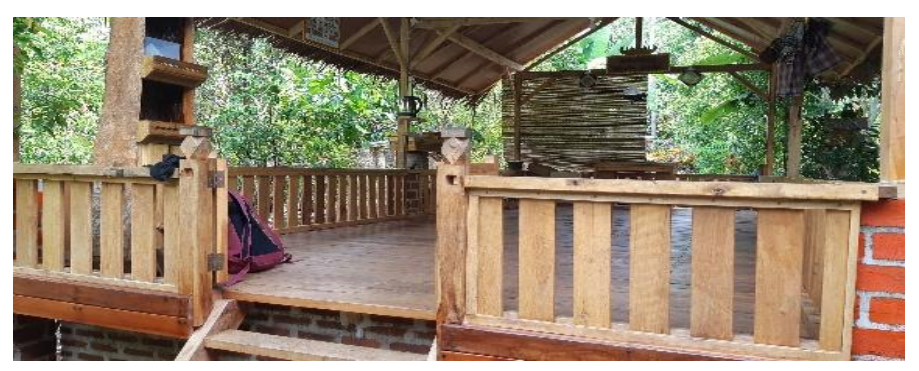

Gambar 6. Kondisi gazebo KLS

Figure 6. Gazebo condition of KLS

Pengunjung mengharapkan adanya penambahan jumlah gazebo guna melengkapi fasilitas lokasi KLS. Hal ini juga dimaksudkan untuk mengantisipasi kunjungan padat wisatawan. Hasil analisis fasilitas KLS menunjukkan bahwa ketersediaan toilet memiliki nilai rata-rata terkecil.

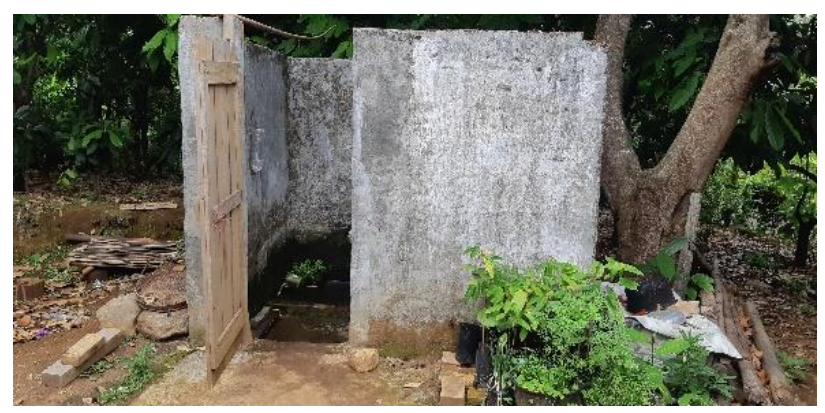

Gambar 7. Kondisi toilet KLS

Figure 7. Toilet condition of KLS

Pengunjung sangat menyayangkan kualitas toilet yang masih sangat minim, terutama jika dibandingkan dengan lokasi budidaya lebah madu yang sudah cukup baik. Indikator mengenai jalan setapak juga tergolong kurang baik. Pengunjung menilai keberadaan jalan setapak dapat memudahkan pengunjung untuk berkeliling, namun melalui kegiatan 
observasi diketahui bahwa tidak seluruh lokasi KLS sudah dilengkapi dengan jalan setapak sehingga.

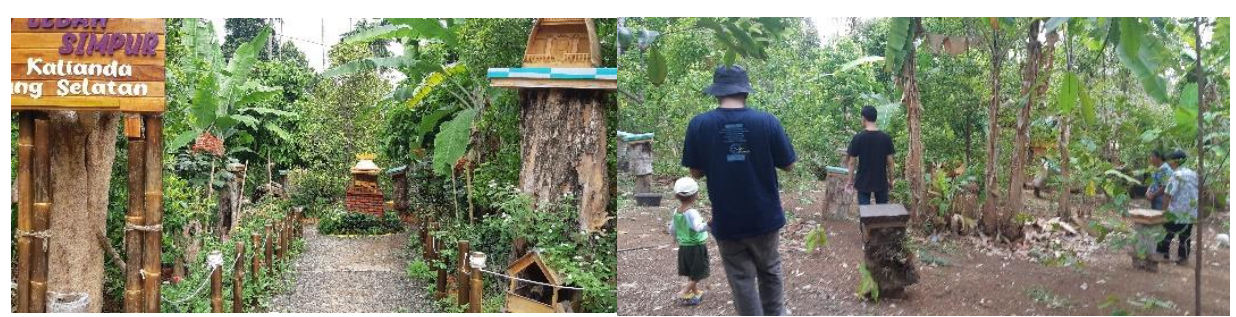

Gambar 8. Kondisi jalan setapak KLS

Figure 8. Walkways condition of KLS

Hasil analisis ini menunjukkan bahwa masih perlunya dilakukan terhadap fasilitasfasilitas yang terdapat di KLS. Karena kurangnya fasilitas yang memadai pada suatu objek wisata dapat menyebabkan pengunjung menghindari objek wisata tersebut (Khotimah et al, 2017).

\section{Analisis Pengelolaan (Ancillary) Oleh Pengunjung}

Analisis persepsi pengunjung mengenai pengelolaan (ancillary) didasarkan pada 12 indikator pertanyaan meliputi keramahan pengelola, kualitas madu, papan informasi, pendidikan, jenis lebah, jenis pakan, guide, harga tiket, harga madu, keramahan masyarakat, keamanan dan kebersihan. Dilakukannya analisis ini guna mengetahui penilaian pengunjung mengenai pengelolaan dan kelembagaan yang telah di terapkan di KLS (Gambar 4).

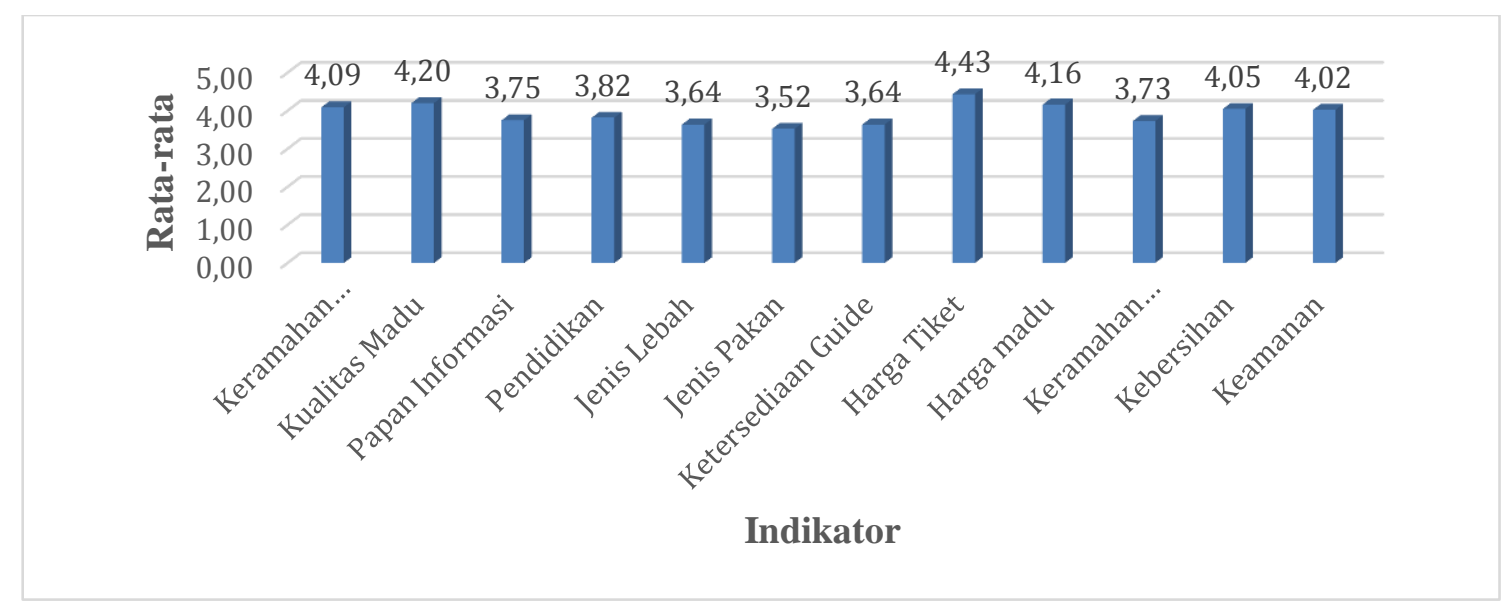

Gambar 9. Analisis persepsi pengelolaan KLS

Figure 9. Perception analys of KLS ancillary

Hasil analisis persepsi pengelolaan (ancillary) oleh pengunjung menunjukkan bahwa penilaian tertinggi terdapat pada indikator harga tiket. Informasi yang diperoleh melalui wawancara mendalam dan pengamatan (Hajriati dan Mardiana, 2014) dengan pihak pengelola menyatakan bahwa tidak ada tarif tiket yang di tetapkan di lokasi KLS. Namun, apabila terdapat kunjungan dari beberapa lembaga maka pihak pengelola hanya 
memberikan biaya kebersihan. Selain indikator tersebut, keramahan pengelola, kualitas madu, harga madu, kebersihan dan keamanan KLS juga tergolong baik, terutama kualitas madu. Karena semakin maraknya peredaran madu palsu saat ini yang cukup sulit dikenali (Koesprimadisari et al, 2016) sedangkan pengunjung dapat langsung melihat proses pemanenan madu di KLS yang terjamin keasliannya, sehingga pengunjung berpendapat bahwa kualitas madu di KLS tergolong baik.

Indikator jenis pakan memiliki nilai rata-rata terkecil. Pakan lebah madu berasal dari berbagai sumber tanaman berbunga yang mengandung nektar (Mulyono et al, 2015). Hal ini disebabkan sebagian pengunjung tidak begitu memperhatikan jenis tumbuhan di sekitar $\mathrm{KLS}$, dan masih beranggapan bahwa pakan lebah hanya didapatkan dari tumbuhan bunga saja. Melalui kegiatan observasi diketahui bahwa kawasan KLS telah ditanami berbagai jenis tumbuhan baik berupa bunga ataupun pepohonan. Pihak pengelola sengaja menanam berbagai jenis tumbuhan berbunga guna mempermudah lebah dalam mengambil nektar, selain produksi nektar dan jumlah koloni sumber pakan juga menjadi salah satu faktur yang mempengaruhi produksi madu lebah (Saepudin, 2010).

Hasil analisis pengelolaan (ancillary) KLS mengenai keberadaan papan informasi, pemberian pendidikan seputar budidaya lebah madu, jenis lebah, ketersediaan guide, dan keramahan masyarakat sekitar lokasi KLS dikategorikan cukup atau netral. Hasil akhir analisis ini menunjukkan bahwa pengelolaan KLS masih harus dikembangkan, guna meningkatkan intensitas kunjungan dan daya tarik (Juwita, 2015) objek wisata. Pengembangan pengelolaan dan kelembagaan ini sangat diperlukan untuk mendukung berlangsungnya kegiatan wisata (Sunaryo, 2013) serta memberikan kepuasan kepada pengunjung (Teguh et al, 2010).

\section{KESIMPULAN dan SARAN}

Hasil analisis persepsi pengunjung yang didasarkan pada faktor 4A (Attraction, Accesability, Amenities dan Ancillary) menunjukkan bahwa persepsi penilaian terhadap daya tarik (attraction) dikategorikan baik. Sedangkan persepsi pengunjung mengenai faktor accesability, amenities dan ancillary tergolong netral sehingga perlunya dilakukan pengembangan, terutama dalam hal pengelolaan dan penambahan fasilitas-fasilitas yang terdapat di KLS sehingga dapat memenuhi kebutuhan pengunjung yang datang ke lokasi tersebut. Bagi pihak pengelola diharapkan dapat melakukan pelatihan terhadap pekerja, agar lebih memahami prinsip wisata dan memungkinkan terlaksananya pemberian informasi yang lebih baik kepada pengunjung.

\section{DAFTAR PUSTAKA}

Adalina, Y. 2011. Analisis financial usaha lebah madu Apis mellifera L. Jurnal Penelitian Hutan dan Konservasi Alam, 5(3), 217-237.

Astriyantika, M., Arief, H. \& Sunarminto, T. 2015. Potensi daya tarik dan persepsi pengunjung terhadap ekowisata laut di Pulau Harapan, taman Nasional Laut Kepulauan Seribu (TNKpS). Jurnal Media Konservasi, 2(3), 235-241.

Bramsah, M. \& Darmawan, A. 2017. Potensi lansekap untuk pengembangan ekowisata di Hutan Lindung Register 25 Pematang Tanggang Kabupaten Tanggamus. Jurnal Sylva Lestari, 5(2), 12-22.

Budiaji, W. 2013. Skala pengukuran dan jumlah respon skala liker. Jurnal IImu Pertanian dan Perikanan, 2(2), 127-133. 
Dewi, M.H.U. Pengembangan desa wisata berbasis partisipasi masyarakat lokal di Desa Wisata Jatiluwih Tabanan, Bali. Jurnal Kawistarara, 3(2), 129-139.

Ekselsa, G., Yuwono, S.B. \& Hilmanto, R. Respon masyarakat terhadap implementasi sistem verifikasi legalitas kayu di kelompok tani makmur Desa Totoprojo Kecamatan Way Bungur Kabupaten Lampung Timur. Jurnal Sylva Lestari, 5(2), 111.

Hajriati, E. \& Mardiana, R. 2014. Pengaruh ekowisata berbasis masyarakat terhadap perubahan kondisi ekologi, sosial dan ekonomi di Kampung Batusuhunan, Sukabumi. Jurnal Sosiologi Pedesaan, 2(3), 146-159.

Haryanto, J.T. Model pengembangan ekowisata dalam mendukung kemandirian ekonomi daerah studi kasus Provinsi DIY. Jurnal Kawistra, 4(3), 271-286.

Khotimah, K., Wilopo. dan Hakim, L. 2017. Strategi pengembangan destinasi pariwisata budaya (studi kasus pada kawasan situs Trowulan sebagai pariwisata budaya unggulan di Kabupaten Mojokerto). Jurnal Administrasi Bisnis (JAB), 41(1), 56-65.

Juwita, I.A.E.R. 2015. Strategi pemasaran Museum Wayang Kekayon Yogyakarta dalam meningkatkan jumlah pengunjung. Jurnal Tata Kelola Seni, 60-74.

Mulyono., Susdiyanti, T. \& Supriono, B. 2015. Kajian ketersediaan pakan lebah madu lokal (Apis cerana Fabr), 15(2), 18-26.

Nugroho, I. 2011. Ekowisata dan Pembangunan Berkelanjutan. Buku. Pustaka Pelajar. Yogyakarta. 362hlm.

Prasetyo, D., Darmawan, A. \& Dewi, B.S. 2019. Persepsi wisatawan dan individu kunsi tentang pengelolaan ekowisata di Lampung Mangrove center. Jurnal Sylva Lestari, $7(1), 22-29$.

Saepudin, R. 2010. Peningkatan produktivitas lebah madu melalui penerapan sistem integrasi dengan kebun kopi. Jurnal Sain Peternakan Indonesia, 6(2), 115-124.

Sadiarta, M. 2006. Ekosistem hutan mangrove: wahana pelestarian alam pendidikan lingkungan. Jurnal Manajemen Pariwisata, 5(1), 4-25.

Sari, Y., Yuwono, S.B. \& Rusita. 2015. Analisis potensi dan daya dukung sepanjang jalur ekowisata hutan mangrove di Pantai Sari Ringgung, Kabupaten Pesawaran, Lampung. Jurnal Sylva Lestari, 3(3), 31-40.

Sugiyono. 2016. Metode Penelitian Kuantitatif, Kualitatif dan R\&D. Buku. PT. Alfabet. Bandung. $464 \mathrm{hlm}$.

Sunaryo, B. 2013. Kebijakan Pembangunan Destinasi Pariwisata Konsep dan Aplikasinya di Indonesia. Buku. Gava Media. Yogyakarta. 159hlm.

Sya'ban, H.M., Wulandari, C. \& Hilmanto, R. 2014. Motivasi petani dalam budidaya lebah madu (Apis cerana) di Desa Buana Sakti Kabupaten Lampung Timur. Jurnal Sylva Lestari, 2(3), 73-82.

Teguh, I.G., Rachmawati, E. \& Masy'ud, B. Studi tentang motivasi dan persepsi pengunjung terhadap pengelolaan pemanfaatan satwa sebagai objek wisata di Satwa Punti Kayu Palembang Sumatera Selatan. Jurnal Media Konservasi, 15(3), 131-138.

Widowati, R. 2014. Studi usaha ternak lebah madu indigenous indonesia apis cerana secara tradisional di Bali. Prosiding Seminar Nasional Prodi Biologi F. MIPA UNHI. 65-72hlm.

Widyarini, I.G.A. \& Sunarta, I.N. 2018. Dampak pengembangan sarana pariwisata terhadap peningkatan jumlah pengunjung di wisata alam air panas angseri, tabanan. Jurnal Destinasi Pariwisata, 6(2), 217-223. 